\title{
Developing 21st-Century Learning Skills through Theatre Arts: A Student-Directed Production
}

\author{
Katherine Movassaghi, M.S. \\ Upper School Head \&Performing Arts Department Chair \\ Episcopal School of Acadiana \\ 1557 Smede Rd. \\ Broussard, Louisiana 70518......USA \\ Roslin Growe, Ed.D. \\ University of Louisiana at Lafayette \\ P. O. Box 43091 \\ Lafayette, LA 70504....USA
}

\begin{abstract}
Research has indicated that the Four C's of 21st century skills - critical thinking, communication, collaboration and creativity are inherent in the development of a well-rounded student. Educational activities that are student led have been shown to positively impact student acquisition of knowledge and add an active dimension to the pedagogy of student involvement. Allowing students to participate in student-directed productions opens up avenues of meaningful lifelong skills and experiences.
\end{abstract}

Keywords: 21st century skills; student-directed productions; the four C's and 21st century learning; theatre arts and student-directed plays

\section{Ouverture: An introduction}

Much has been written over the last 20 years about what set of skills students in the 21 st century need to be successful, and how those skills contrast with the ones promoted by previous generations. Jobs that require repeated tasks, such as in factories, are becoming less and less necessary and available (Voogt and Roblin, 2012), leading to the necessity for more complex thinking skills in current society. A 21st-century skill set needs to be "associated with higher order skills and behaviorus that represent the ability to cope with complex problems and unpredictable situations" (Voogt and Roblin, 2012, p. 300).

While it is important in this new century for students to know how to use technology and to have digital literacy more so than 20 years ago, it is imperative for students to employ other skills to effectively use and enhance technology (Binkly as cited in Hakkinen et al, 2017; Voogt and Roblin, 2012). Interpersonal and communication skills remain important to the success of one's career and life and these skills have been important for thousands of years. What is apparent in the 21 st century learner is an opportunity to connect the interpersonal learner (relationships and respect) to the intellectual learner (academic and technical knowledge) in order to maximize success in an increasingly globalized society and economy that previous generations did not. The playing field for our students today is much bigger than it ever was. Today's students are a part of a "knowledge society" (Voogt and Roblin, 2012, p. 300.) However, what kind of knowledge is that?

The premise of this concept is to connect the arts, particularly the theatre, through active student involvement leading to student-directed productions. Touting the importance of the arts, the impetus is on encouraging student-directed productions which offer multiple benefits. Some benefits are: allowing student directors to be discerning, analytical, practical, speculative, theoretical, exposure to theatrical elements including directing skills, being self-directed, creative, self-monitored, displaying playwriting abilities, stage management, acting techniques, collaborating, and leadership skills. Knowledge plus an array of experiences are gained because of the extensive amount of work that goes into the production of a play.

\section{Act I: 21st-century skills and the 4 C's}

What are 21st century skills? Simply put, they refer to the worldwide communication and connections that students have access to today and how their skills they are learning in school affect, enhance, or even detract from that fact. People live in an increasingly diverse and globally connected society. 
Do school-aged children have the tools not only to navigate this new world but also know about how to relate to, understand, and communicate with people toward a successful end? According to P21 Partnership for 21st Century Learning (n.d.), the $4 \mathrm{C}$ 's emerged as the main skills for 21 st century learnings: creativity, communication, collaboration, and critical thinking. Kereluik, Mishra, Fahnoe, \& Terry (2014) extended this definition even further by conducting an analysis of 15 frameworks of 21 st century learning put forth by various education groups. Synthesized, they created one visual image, called a $3 \times 3$ model (Figure 1), which combines foundation knowledge (to Know), meta knowledge (to Act), and humanistic knowledge(to Value).

One element of the model is not more superior to the other (Mishra \& Mehta, 2016). All must be cultivated in a student at the samelevel.

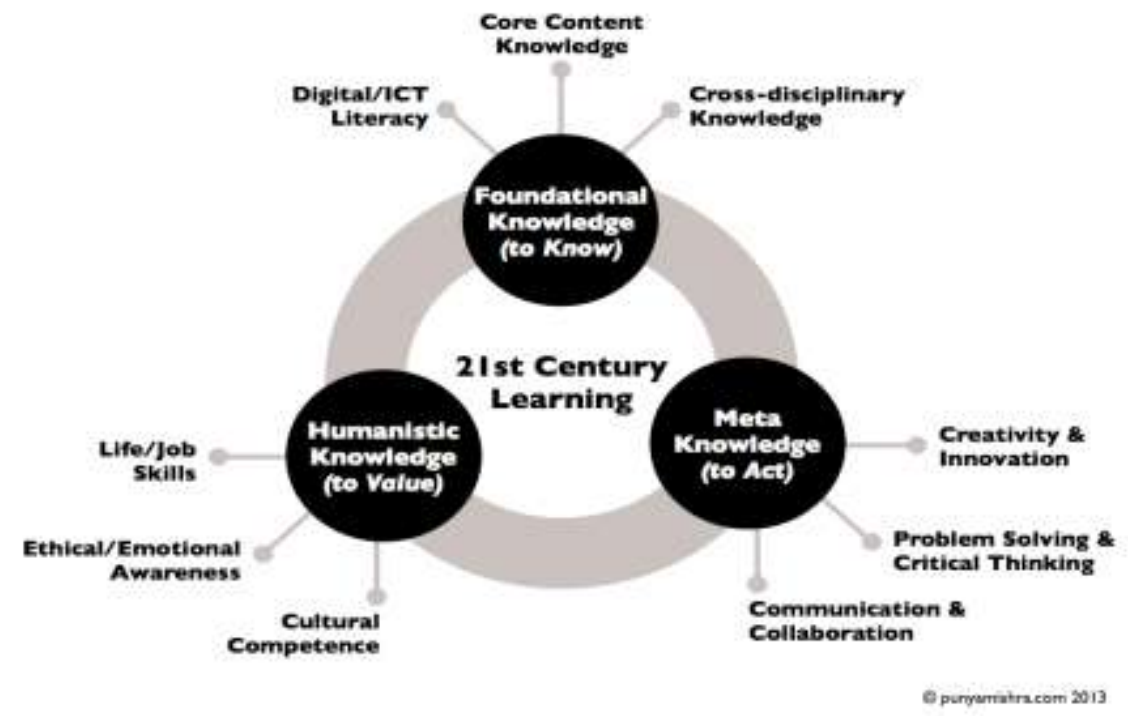

It is the contention of Kereluik, et al (2013) that there is not necessarily one, two or three specific skills that students must learn. Educators have an obligation to create a curricula that personifies all of the aforementioned skills as much as possible. A comparison of eight international frameworks for 21 st century competencies suggested that, across many different cultures, there were "strong agreements on the need for competences in the areas of communication, collaboration, ICT-related competences, and social and/or cultural awareness. Creativity, critical thinking, [and] problem-solving....are also regarded as important" (Voogt \& Roblin, 2012, p. 308). If students are trained in all of these aspects, they will be ready to meet the future more so than if they focused on one. Within this model lie the $4 \mathrm{C}$ 's, but those C's are nothing without fundamental, core content knowledge, cultural competence, and a high emotional quotient.

\section{Act II: A collaborative and learner-centered environment}

Collaborative learning is one of the best ways to teach these 21 st century skills, because this type of learning combines social skills and knowledge (Häakkinen et al, 2017). Collaborative learning allows students to ask each other questions, articulate points, listen to others, and incorporate knowledge of a group addressing all elements in the $3 \times 3$ model (Kereluik, et al., 2013). Simply put, students learn how to get along with each other through a collaboration of problem solving (CPS) and socially shared regulations (SSRL) (Häakkinen et al, 2017).

Learner-centered lessons that are driven by and executed by the students allow them to discover not only where the gaps are in their existing knowledge but also how to overcome them. In essence, students take control of their learning (Häakkinen et al, 2017), making the learning more authentic and assuring more retention for the processes and goals of the lesson.

A drama class is an ideal setting for students to practice this model. It is a fluid curriculum, with a relaxed setting, and a creative atmosphere that causes most students to be at ease. Interpersonal communication, people skills, content knowledge, creativity, problem solving, and collaboration are all hallmarks of play production. To have a student director means that the teacher is truly enacting all elements of the $3 \times 3$ model and highlighting the themes of a collaborative and learner-centered classroom. Additionally, the theatre arts classroom develops more critical thinking skills, as students move toward problem-solving collaboratively and creatively. 
These skills are developed by honing social skills as a cast as well as creating original solutions toward bringing the production to fruition (Winner, Goldstein, \& Vincent-Lancrin, 2013).

The National Core Arts Standards for performing and visual arts in grades PK through 12 (www.nationalartsstandards.org, 2014) lists their four standards as creating, performing/presenting/producing, responding, and connecting. These standards are woven throughout the 21 st-century skill set, making theatre an even more exciting place to put them in action to improve student skills.

\section{Intermission: A break before moving on}

If theatre teachers are interested in using a student-director as a way of advancing some of those 4C's skills, they might begin with establishing the following guidelines with the student-director:

- Establish parameters--guidelines (how class is organized, what are the classroom rules, a general lesson plan)

- Choose plays.

- Determine if the student wishes to serve as the director or perform in the play as well.

- Set up the rehearsal schedule for the cast with established expectations and deadlines.

- Create specific checkpoint dates with the student to assess mental health and any other practical issues.

- Determine the teacher's role in this process. Does the student want the teacher to be very involved or sit off to the side, participating only when needed?

- Depending on the depth of the project and needs of the student director, determine who will take care of technical/facility issues, programs, costumes, and set design. Will it be a crew member, the teacher, cast members, or the student-director?

- Reflection piece at the closing of the production.

\section{Act III: Anticipating the journey}

How does the student-directed play process work out? The following are questions that a teacher might anticipate on the journey toward using theatre to enhance 21 st-century learning skills.

What type of student shows an interest in directing a play?

- likes to be in control

- is very passionate about theatre

- wants to learn another side of the craft

- likes to challenge people in a non-stressful way

How can the student-director benefit from this experience? By becoming more responsible for their own learning and how they impart it. Through the process of directing peers toward solutions, learning becomes more authentic, forcing them to face the challenge of analyzing specificdetails of the situation and work toward a solution together which cements theintended learning (Hiller and Paul, 2006) and makes theatre arts a key discipline toward developing social and professional skills (Winner, Goldstein, \& Vincent-Lancrin, 2013). In essence, what the lead teacher is teaching, the student-director is applying critical thinking skills, again in line with the 4C's.

The theatre classroom is an excellent place to learn to think critically, as there are multiple opportunities for problem solving. A student-director benefits by...

- Learning more about acting by directing other students

- Becoming a better actor by directing other students

- Getting a better perspective of the craft of acting and theatre

- Understanding issues from a director's point of view, such as what causes their stress

- Enabling all parties to develop and enhance acting skills as well as to grow interpersonally

- Sharpening communication skills

- Recognizing and managing control issues

- Teaching self-discipline

- Teaching how to lead and communicate effectively. How will the student-director get peers (some of whom are not as passionate about theatre) to follow his or her lead and accomplish something without losing their interest?

- Introducing the establishment of authority while not being overly threatening while still influencing others to accomplish the goal

- Taking responsibility for a final product

- Practicing perseverance. How does the student handle stress and roadblocks?

- Practicing flexibility. How does the student adapt when things aren't going well, or people aren't meeting your style?

- Feeling pride and accomplishment in a job completed and produced for the public. 


\section{Act IV: What about the "real" teacher?}

Switching roles with a student may be difficult for some teachers, whether in the theatre classroom or in another discipline. Many teachers, especially theatre directors, are accustomed to making decisions and directing the path of the production. Recognizing the need for control but also relinquishing it (within reason) is key to the teacher's growth as well. Are there new techniques that teachers can learn from the student? If teachers take a step back and observe rather than direct, what big-picture themes will they see emerge from this group of students and in this space, that maybe they cannot see when immersed in the day-to-day duties? The teacher becomes an active learner, essentially participating in on-site and relevant professional development (Zepeda, 2019). Teachers will learn that having a student direct the class is educational for them as well. There is mutual growth between adults and students in this process; having a studentdirector can be the ultimate lesson plan for student learning (Hiller and Paul, 2006).

\section{Act V: Conclusion}

Student-directors may find the process exciting but difficult, especially with managing different personalities. It may be harder than they anticipated but may also bring great personal rewards. Consistent dialogue with the teacher is necessary as this is an incredible learning experience for all involved. Reflections may recognize the difficulties of some choices; for example, the stress that might come with directing and performing in the play. Other issues could be the stress that comes with managing people (in particular, their peers) toward accomplishing a goal especially when some do not meet established deadlines, benchmarks, or have the same work ethic. Handling those issues is where the professional's expertise in education can be of additional service.

The skills touted in the 21st-century student--creativity, communication, collaboration, and critical thinking--are not new to humanity (Häakkinen et al, 2017). Specifically, it is the element of creativity that has enabled humans to adapt and survive (Jerome, 2019). The 4C's are old skills but must be adapted in different ways for issues in the 21st century (Voogt \& Roblin, 2012).

At the metaphorical curtain call, teachers should provide students with the necessary tools as delineated in the 4C's not only for personal satisfaction but in the advancement of humankind. Additionally, Students can have fun while doing it and feel proud of themselves. That is the beauty of the theatre classroom and a student-directed production.

\section{References}

Dayton, T. (2015). Performing arts students develop skills needed for life and work. National Federation of State High School Associations. December 21, 2015.

Häakkinen, P., Järvelä, S., Mäkitalo-Siegl, K., Ahonen, A., Näykki, P., \& Valtonen, T. (2017). Preparing teacherstudents for twenty-first century learning practices (PREP 21): A framework for enhancing collaborative problem-solving and strategic learning skills. Teachers and Teaching: Theory and Practice, 23(1), 25-41. Doi: 10.1080/13540602.2016.1203772.

Hiller, W. and Paul, R. (2006). The miniature guide to practical ways for promoting active and cooperative learning. Lanham, MD: Rowman \& Littlefield.

Jerome, R. (2019). Striving for the new. Time Special Edition: The Science of Creativity, 4-9.

Kereluik, K., Mishra, P., Fahnoe, C., \& Terry, L. (2013). What knowledge is of most worth: Teacher knowledge for 21 st century learning. Journal of Digital Learning in Teacher Education, 29(4). 127-140.

Doi: 10.1080/21532974.2013.10784716.

Mishra, P. and Mehta, R. (2017). What we educators get wrong about 21 st-century learning:

Results of a survey. Journal of Digital Learning in Teacher Education, 33(1). 6-19. Doi: 10.1080/21532974.2016.1242392.

National core arts standards (2014). Retrieved from https://www.nationalartsstandards.org.P21: Battelle for Kids (n.d.). P21 Partnership for 21st Century Learning. Retrieved from http://www.battelleforkids.org/networks/p21.

Voogt, J. and Roblin, N.P. (2012). A comparative analysis of international frameworks for 21st-centry competences: Implications for national curriculum policies. Journal of Curriculum Studies, 44(3), 299-321.

Doi: 10.1080/00220272.2012.

Winner, E., Goldstein, T. R., \& Vincent-Lancrin, S. (2013). Educational research and innovation. Art for art's sake? The impact of arts education. Paris Cedex 16, France: OECD Publishing. http://dx.doi.org/10.1787/9789264180789-en.

Zepeda, S.J. (2019). Professional development: What works? (3rd Ed.) New York, NY: Taylor \& Francis. https://doi.org/10.4324/9781315386744. 